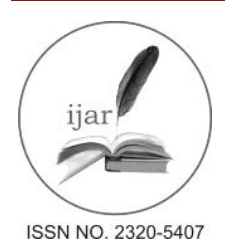

\author{
Journal homepage: http://www.journalijar.com \\ Journal DOI: $10.21474 /$ IJAR01
}

INTERNATIONAL JOURNAL

OF ADVANCED RESEARCH

RESEARCH ARTICLE

\title{
A NEW SPERM PREPARATION TECHNIQUE BY COMBINATION OF DENSITY GRADIENT CENTRIFUGATION AND GLASS WOOL FILTRATION TECHNIQUES VERSUS EACH ONE ALONE FOR INFERTILE MEN WITH ASTHENOZOOSPERMIA
}

\author{
Ezdehar N. Ali, Ula M. R. Al-Kawaz", Muhammad-Baqir M-R. Fakhrildin. \\ High Institute for Infertility Diagnosis and Assisted Reproductive Technologies, Al-Nahrain University, Baghdad- \\ IRAQ.
}

\section{Manuscript Info}

Manuscript History:

Received: 14 February 2016

Final Accepted: 19 March 2016

Published Online: April 2016

Key words:

Asthenozoospermia, Density gradient centrifugation technique, Glass wool filtration technique, Max pure technique (combination technique) and in vitro sperm activation.

*Corresponding Author

Ula M. R. Al-Kawaz.

\begin{abstract}
Background:- A variety of techniques have been developed to separate motile and morphologically normal spermatozoa from other constituents of the ejaculate to optimize successful assisted reproductive techniques.

Objectives:- To compare the asthenozoospermic semen outcomes of three in vitro sperm activation (ISA) techniques and evaluate the efficacy, namely; Density gradient centrifugation (DGC) technique, Glass wool filtration technique and Max pure technique(combination of DGC and GWF techniques).

Methods:- Forty three infertile men with asthenozoospermia were involved in this study. Sperm parameters assessed according to WHO (2010 and 1999). Post- activation of each sample divided into three aliquots, the first one using DGC, the second using GWF, and last one using Max pure technique.

Results:- A significant increase $(\mathrm{P}<0.05)$ of sperm motility, progressive sperm motility and normal sperm morphology when using Max pure technique as compared to DGC and GWF techniques. Also, there was a significant increase $(\mathrm{P}<0.05)$ for the same parameters when using $\mathrm{DGC}$ technique as compared to the GWF technique.

Conclusions:- Using Max pure technique for semen sample with decreased in the sperm motility were superior to that of DGC and GWF techniques.
\end{abstract}

\section{Introduction:-}

Infertility is defined as failure of a couple to conceive after twelve months of regular intercourse without the use of contraception in women less than 35 years of age and after six months of regular intercourse without the use of contraception in women of 35 years and older ${ }^{(1)}$. It affects approximately $15 \%$ of couples worldwide and negatively influences the quality of life in those couples who are affected ${ }^{(2)}$.

Assisted reproductive technologies (ART's) have become the treatment of choice in many cases for male and female infertility. The quality of semen samples is one of the factors determining the successful assisted reproduction ${ }^{(3)}$. Therefore, the ideal sperm preparation technique is to achieve the largest number of morphologically normal, motile spermatozoa in a small volume of physiological culture media free from seminal plasma, leukocytes and bacteria ${ }^{(4)}$. With the advancement in the techniques of assisted reproduction, the need to improve sperm processing methods and provision of actively motile spermatozoa has increased tremendously ${ }^{(5)}$. However, DGC technique consistently produces semen samples of the highest quality required for the intrauterine insemination (IUI) and for in vitro fertilization (IVF) which explains why it is the preferred sperm processing method ${ }^{(6,7,8)}$. The DGC technique that 
separates spermatozoa is based on their density. Thus, at the end of the centrifugation, each spermatozoon is located at the gradient level that matches its density ${ }^{(9)}$.

The advantage of this DGC method is that it can be used in cases with a low sperm concentration and motility ${ }^{(10)}$. While the disadvantages of this method include, the risk of contamination with endotoxins and the production of good interphases between layers can take some time ${ }^{(11)}$.

The principle of GWF technique is rested on the self-propelled movement of the spermatozoa and filtration effect of the glass wool fibers ${ }^{(12)}$. A major advantage of this approach is the selection of normally chromatin- condensed spermatozoa, a parameter considered as predictive for fertilization ability in vitro. The GWF technique is very simple but it is a more expensive procedure ${ }^{(13)}$. Some debris is usually still present in the sample after the glass wool filtration ${ }^{(11)}$.

Asthenozoospermia is one of the major causes of infertility or reduced fertility in men ${ }^{(14)}$. Asthenozoospermia, is defined as 'total motility' (progressive + non-progressive) less than $40 \%$ or progressive motility less than $32 \%$ $(\mathrm{WHO}, 2010)^{(15)}$.

Sperm motility is a critical indicator of semen quality and fertility potential because the sperm motility is required for the penetration of cervical mucus, transport through the female genital tract and penetration through the corona radiate and zona pellucid before oocyte fertilization ${ }^{(16)}$.

\section{Materials and Methods:-}

Forty three infertile men with asthenozoospermia participated in this study during their attendance to the infertility clinics at the High Institute for Infertility Diagnosis and Assisted Reproductive Technologies, Al-Nahrain University and the Infertility unit of Al -Hussein Teaching Hospital -Thi-Qar. Semen samples were collected and semen analysis was done according to WHO (2010) and (1999). Each semen sample was divided into three aliquots. The first one using the density gradient centrifugation technique, the second one using glass wool filtration technique, while the third one using Max pure technique(combination technique), then sperm parameters were assessed for these three techniques and the results were statistically analyzed.

\section{Max Pure Technique (combination technique):-}

As a new sperm preparation technique was performed as the following, adding $1 \mathrm{~mL}$ of $80 \%$ of Sil-Select Plus gradient as a first layer solution in a test tube followed by $1 \mathrm{~mL}$ of $40 \%$ of Sil-Select Plus gradient as a second layer solution then liquefied semen sample was added on the second layer. This test tube was carefully put in centrifuge at $2600 \mathrm{rpm}$ for 15 minutes. Supernatant discarded and $1 \mathrm{~mL}$ of Ferticult Flushing medium added to the pellet. Shaking the sample then left for 8-10 minutes in an incubator, after that the semen suspension placed gently over the wet glass wool syringe and allowed to filter by gravity. A drop of $10 \mu \mathrm{L}$ was aspirated, put on a slide with cover slip and examined under the microscope at 400X objective to assess the sperm parameters as recommended by WHO (2010) and (1999).

\section{Statistical Analysis:-}

The data were statistically analyzed using Statistical package for social sciences (SPSS) version 20 software. Sperm parameters, pre and post activation assay were analyzed using (one way ANOVA).

\section{Results:-}

Table 1: Sperm parameters for infertile men with asthenozoospermia (no.43: 43\%), pre- and post-in vitro sperm activation techniques. The present study showed a significant decrease $(\mathrm{P}<0.05)$ in the certain sperm parameters (sperm concentration, sperm agglutination and round cells count) post-ISA when using these three techniques as compared to pre- activation. While, a significant increase $(\mathrm{P}<0.05)$ in the other certain sperm parameters (sperm motility, progressive sperm motility and normal sperm morphology) post- ISA when using these three activation techniques as compared to pre-activation. The same table showed a significant decrease $(\mathrm{P}<0.05)$ for the concentration of sperm when using Max pure technique as compared with the GWF technique. In contrast, this table (1) showed significant increase $(\mathrm{P}<0.05)$ in the certain sperm parameters (sperm motility, progressive sperm motility and normal sperm morphology) when using Max pure technique as compared with the DGC and GWF techniques. While, a significant increase $(\mathrm{P}<0.05)$ for the same sperm parameters when using DGC technique as 
compared to GWF technique. This table showed non- significant difference $(\mathrm{P}>0.05)$ for the sperm agglutination and round cells count among these three activation techniques.

Table 1: Sperm parameters for asthenozoospermic infertile men pre- and post- in vitro sperm activation.

\begin{tabular}{|c|c|c|c|c|c|}
\hline \multirow{2}{*}{\multicolumn{2}{|c|}{ Sperm parameters }} & \multirow[t]{2}{*}{ Pre- activation } & \multicolumn{3}{|c|}{ Post- activation } \\
\hline & & & $\begin{array}{l}\text { Density } \\
\text { gradient }\end{array}$ & Glass wool & Max pure \\
\hline \multicolumn{2}{|c|}{ Sperm concentration (millions/mL) } & $\begin{array}{l}40.348 \text { a } \\
\pm 2.326\end{array}$ & $\begin{array}{l}18.976 \mathrm{bc} \\
\pm 1.085\end{array}$ & $\begin{array}{l}22.465 \mathrm{~b} \\
\pm 1.224\end{array}$ & $\begin{array}{l}15.139 \mathrm{c} \\
\pm 0.998\end{array}$ \\
\hline \multicolumn{2}{|c|}{ Sperm motility (\%) } & $\begin{array}{l}51.558 \mathrm{~d} \\
\pm 1.331\end{array}$ & $\begin{array}{l}84.790 \mathrm{~b} \\
\pm 0.548\end{array}$ & $\begin{array}{l}81.139 \text { c } \\
\pm 0.565\end{array}$ & $\begin{array}{l}90.093 \text { a } \\
\pm 0.439\end{array}$ \\
\hline \multirow{3}{*}{ 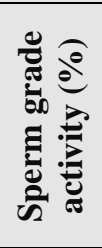 } & $\begin{array}{l}\text { Progressive sperm } \\
\text { motility }(\%)\end{array}$ & $\begin{array}{l}22.325 \mathrm{~d} \\
\pm 0.737\end{array}$ & $\begin{array}{l}71.023 \mathrm{~b} \\
\pm 0.458\end{array}$ & $\begin{array}{l}64.511 \mathrm{c} \\
\pm 0.492\end{array}$ & $\begin{array}{l}80.046 \text { a } \\
\pm 0.499\end{array}$ \\
\hline & $\begin{array}{l}\text { Non Progressive sperm } \\
\text { motility }(\%)\end{array}$ & $\begin{array}{l}29.232 \text { a } \\
\pm 0.967\end{array}$ & $\begin{array}{l}13.697 \mathrm{c} \\
\pm 0.341\end{array}$ & $\begin{array}{l}16.627 \mathrm{~b} \\
\pm 0.379\end{array}$ & $\begin{array}{l}10.046 \mathrm{~d} \\
\pm 0.310\end{array}$ \\
\hline & Immotile sperm (\%) & $\begin{array}{l}48.441 \mathrm{a} \\
\pm 1.319 \\
\end{array}$ & $\begin{array}{l}15.279 \mathrm{c} \\
\pm 0.567\end{array}$ & $\begin{array}{l}18.860 \mathrm{~b} \\
\pm 0.565\end{array}$ & $\begin{array}{l}9.907 \mathrm{~d} \\
\pm 0.439 \\
\end{array}$ \\
\hline \multicolumn{2}{|c|}{ Normal sperm morphology (\%) } & $\begin{array}{l}38.255 \mathrm{~d} \\
\pm 0.603\end{array}$ & $\begin{array}{l}68.767 \text { b } \\
\pm 0.403\end{array}$ & $\begin{array}{l}63.465 \mathrm{c} \\
\pm 0.467\end{array}$ & $\begin{array}{l}75.255 \text { a } \\
\pm 0.504\end{array}$ \\
\hline \multicolumn{2}{|c|}{ Sperm agglutination $(\%)$} & $\begin{array}{l}9.279 \text { a } \\
\pm 1.316\end{array}$ & $\begin{array}{l}0.093 \mathrm{~b} \\
\pm 0.064\end{array}$ & $\begin{array}{l}0.00 \text { b } \\
\pm 0.00\end{array}$ & $\begin{array}{l}0.00 \mathrm{~b} \\
\pm 0.00\end{array}$ \\
\hline \multicolumn{2}{|c|}{ Round cells count (HPF) } & $\begin{array}{l}6.441 \text { a } \\
\pm 0.535\end{array}$ & $\begin{array}{l}0.00 \mathrm{~b} \\
\pm 0.00\end{array}$ & $\begin{array}{l}0.581 \text { b } \\
\pm 0.142\end{array}$ & $\begin{array}{l}0.00 \quad b \\
\pm 0.00\end{array}$ \\
\hline
\end{tabular}

- Means with different superscripts within each row are significant different $(\mathrm{P}<0.05)$ in which $(\mathrm{a})$ is the highest value while (d) is the lowest value

- Means with similar superscripts within each row are non -significant different $(\mathrm{P}>0.05)$

- Data are mean \pm S.E

- $\quad$ Number $=43$

\section{Discussion:-}

Sperm preparation techniques are a vital component of assisted reproductive technologies ${ }^{(17)}$. Meanwhile, improvement in the sperm parameters enhanced the sperm fertilizing capacity and outcomes of ART's ${ }^{(18,19)}$.

Importantly, the idea of sperm separation techniques is to treat the spermatozoa in vitro in order to improve their functionality i.e. motility and supply a protective environment with the purpose to maintain or improve their functional capacity for successful fertilization. An improvement in the percentages of sperm motility and progressive sperm motility is regarded as normal response for sperm activity after removal of seminal plasma since it contain dead sperm, leukocytes, epithelial cells, debris and microbial contamination that produce many oxygen radicals that can negatively influence the sperm functions ${ }^{(20)}$. The current study clarified that significant increase $(\mathrm{P}<0.05)$ for the progressive sperm motility after ISA when using Max pure technique as compared to the DGC and GWF techniques. Also, this study clarified that a significant increase $(\mathrm{P}<0.05)$ for the same parameter postactivation when using the DGC technique as compared to the GWF technique. The present study clarified that a significant increase $(\mathrm{P}<0.05)$ in the normal sperm morphology when using Max pure technique as compared to the DGC and GWF techniques. Significant increase $(\mathrm{P}<0.05)$ for the same parameter when using DGC technique as compared to GWF technique. Sperm morphology is considered as a sensitive indicator of overall testicular health, because the sperm morphological characteristics are determined during spermatogenesis ${ }^{(21)}$. Also plays a crucial role in the diagnosis of male fertility potential and it has demonstrated a predictive value for fertilization and pregnancy outcomes in $\mathrm{IVF}^{(22)}$. 


\section{References:-}

1. Practice Committee of the American Society for Reproductive Medicine. Definitions of infertility and recurrent pregnancy loss. Fertil Steril. 2008; 90:560.

2. Esteves SC, Miyaoka R and Agarwal A. An update on the clinical assessment of the infertile male. Andro Hum Reprod. 2011; 66(4):691-700.

3. Said TM, Grunewald S, Paasch U, et al. Advantage of combining magnetic cell separation with sperm preparation techniques. Reprod. Biol. Med. 2005; 6: 740-746.

4. Van Voorhis BJ. Outcomes from assisted reproductive technology. Obstet Gynecol. 2006;107:183-20. Press 2010.pp.167-87

5. Noah L, Jain T, Missmer SA and Hornstein MD. Trends in Assisted Reproductive Technology. N Engl J Med. 2004;35: 398-9.

6. Zini A, Nam RK, Mak V, et al. Influence of initial semen quality on the integrity of human sperm DNA following semen processing. Fertil Steril. 2000; 74:824-827.

7. Brahem S, Mehdi M, Landolsi $\mathrm{H}$, et al. Semen parameters and sperm DNA fragmentation as causes of recurrent pregnancy loss. Urology. 2011; 78:792-796.

8. Jayaraman V, Upadhya D, Narayan PK, et al. Sperm processing by swim-up and density gradient is effective in elimination of sperm with DNA damage. J Assist Reprod. 2012; 29:557-563.

9. Bjorndahl L, Mortimer D, Barratt CLR, et al. Sperm Preparation: A Practical Guide to Basic Laboratory Andrology. $1^{\text {st }}$ edn. USA: Cambridge University Press. 2010; 167-87.

10. Petyim S, Choavaratana R, Suksompong S, et al. Outcome of Sperm Preparation Using Double-Gradients Technique Study in Siriraj Hospital. J Med Assoc Thai. 2009; 92 (7): 878-84.

11. Beydola T, Sharma RK, Lee W, et al. Sperm preparation and selection techniques. In: Rizk B, Aziz N and Agarwal A. Editors. Male Infertility Practice. New Delhi: Jaypee Brothers Medical Publishers. 2013;244-251.

12. Sanchez R, Concha M, Ichikawa T, et al. Glass wool filtration reduces reactive oxygen species by elimination of leukocytes in oligozoospermic patients with leukocytospermia. J Assist Reprod Genet. 1996;13:489-94.

13. Henkel R, Kierspel E, Stalf T, et al. Effect of reactive oxygen species produced by spermatozoa and leukocytes on sperm functions in non-leukocytospermic patients. Fertil Steril. 2005; 83(3): 635-42.

14. Aitken RJ, Baker MA and Nixon B. New insights into sperm physiology and pathology. Handb Exp Pharmacol. 2010;(198):99-115.

15. World Health Organization. WHO laboratory manual for the examination and processing of human semen. $5^{\text {th }}$ edition. Geneva: World Health Organization . 2010.

16. Hadwan MH, Almashhedy LA and Alsalman AS. The key role of zinc in enhancement of total antioxidant levels in spermatozoa of patients with asthenozoospermia. Am J Mol Cell Bio. 2013;1: 52-61.

17. Betancourt M, Resendiz A and Fierro. Effect of two insecticides and two herbicides on the porcine sperm motility patterns using computer assisted semen analysis (CASA) in vitro Reprod. Toxicol. 2006; 22: 508-12.

18. Bavister BD, Kinsey DL, Lane M, et al. Recombinant human albumin supports hamster in vitro fertilization. Hum Reprod 2003; 18: 113- 6.

19. Grasa P, Perez P, Baguena O, et al. Ram sperm selection by a dextran/swimup procedure increase fertilization rates following intrauterine insemination in superovulated Ewes. J. Androl. 2004; 25: 786-790.

20. Bjorndahl L, Mohammadieh M, Pourian M, et al. Contamination by seminal plasma factors during sperm selection. J Androl.2005; 2: 170-73.

21. Turek PJ. Male infertility. In: Tangho EA and Aninch MC (Eds). Smith general Urology. lange medical Book. Newyork: McGraw Hill. 2001; 750-787.

22. Antinori M, Licata E, Dani G, et al. Intracytoplasmic morphologically selected sperm injection: a prospective randomized trial.2008; 16, 6: 835-841. 